\title{
Muslim Consumers Style Inventory: A Case from Pakistan
}

\author{
Shoaib Shafique ${ }^{1}$, Mubashar Hassan Zia ${ }^{2 *}$, Amer Rajput ${ }^{3}$, Khurram Shafi ${ }^{4}$, \\ Aamer Shareef ${ }^{5}$ \\ ${ }^{1}$ Lecturer at FMS, Riphah International University, Islamabad, Pakistan \\ ${ }^{2}$ Assistant Professor at FMS, Riphah International University, Islamabad, Pakistan \\ ${ }^{3}$ Assistant Professor at Department of Management, COMSATS University, Wah Cantt, Pakistan \\ ${ }^{4}$ Assistant Professor at department of Management, COMSATS University, Wah Cantt, Pakistan \\ ${ }^{5}$ Lecturer at FMS, Riphah International University, Islamabad, Pakistan
}

\section{Keywords \\ Muslim Consumers, \\ Shopping \\ Orientations, Impulsive Buying, \\ Price and Quality \\ Conscious}

Received: 30-Mar-19

Accepted: 14-Jul-19

\begin{abstract}
The primary objective of the study is to investigate the Muslim consumers' style inventory. An allied objective of this study is to test the reliability and validity of Consumer Style Inventory (CSI) in an economically developing country like Pakistan. For this purpose, data was collected from university graduate and under-graduate students. Factor reduction technique was used in SPSS to examine Muslim consumers' style inventory. Findings of the study indicate that Muslim consumers are partially different from their non-Muslims counterparts. The result of principal component analysis revealed that factors like "Impulsive" and "recreational" were not confirmed by the Muslim consumers. However, other factors like price conscious, quality conscious and 'confused by over choice' were confirmed. Thus, study suggests that formal consumers' education system should be enhanced and all concerned bodies like Islamic scholars, Government agencies and universities should play their role in formulating shopping orientation of Muslim consumers. Furthermore, the future direction of study provides an avenue to coming scholars on the area.
\end{abstract}

KAUJIE Classification: $\mathrm{H} 54$, P1

JEL Classification: M3, Z12

(C) 2019 JIBM. All rights reserved.

\section{INTRODUCTION}

Consumers have been using increasingly different decision-making styles. Through rapid technological inventions, information overload, bombardment of advertisement and with paradox of choices; decision making has become more complex than in the recent past. Complexity of choices not only affects consumers, but also the practitioners, because they face more difficulty in building profitable relationship with customers through satisfaction.

\footnotetext{
*Corresponding author: Mubashar Hassan Zia

†Email: mubashar.hassan@ riphah.edu.pk
} 
Scholars have considered shopping as a complex and complicated procedure integrated by many factors. McDonald (1994) argued that buying decisions can be affected by many factors, and these factors can vary according to the segments. Previously, scholars have identified different consumers styles or motives which significantly affected consumers' buying behaviours such as financial, loyalty, convinced or not, quality orientation, comparison and fashion motives (Bakewell \& Mitchell, 2003; Bettman, 1979; Jacoby, Chestnut, \& Fisher, 1978; Korgaonkar, 1984; Maynes, 1976; Miller, 1981; Stephenson \& Willett, 1969; Stone, 1954). Considering the importance of the construct, Sprotles and Kendall (1986) conceptualized eight basic characteristics of the styles and developed a comprehensive CSI. They defined it as the "basic consumer personality". Similarly, Walsh, Hennig-Thurau, Wayne-Mitchell, and Wiedmann (2001) defined it as "basic buying-decision-making attitudes that consumers adhere to, even when they are applied to different goods, service or purchasing decisions".

Since the term CSI was coined, the concept was tested in different regions on target audiences. In beginning, Sprotles and Kendall (1986) tested the concept on American students, then Hafstrom, Chae, and Chung (1992) investigated Korean students; Hiu, Siu, Wang, and Chang (2001) worked on Chinese, Lysonski, Durvasula, and Zotos (1996) worked on Greek, Likewise Patel, Vila-López, and Kuster-Boluda (2013) used Indian sample; Walsh, Mitchell, and Hennig-Thurau (2001) tested concept on Germans; Bates (1998) used British sample; Radder, Li, and Pietersen (2006) examined Thrikish sample; Kavas and Yesilada (2007) investigated South African students and more recently Aliman, Ariffin, and Hashim (2017) tested the CSI concept on Malay culture and pointed towards the future exploration of this concept in other cultures.

Thus, the past studies trend shows that researchers have remained focused on examining the CSI from cultural and economic regional perspective only. However, culture itself is nothing but a belief system (Schommer-Aikins, 2004). As noted by Delener (1990), religion is critical cultural driver and important predecessor of consumer behaviour. Literature undoubtedly identifies that religion guides individuals' behaviour from simple daily routine issues like household spending (Renneboog \& Spaenjers, 2012) to complex corporate affairs and marriage decisions (Hilary \& Hui, 2009; Sigalow, Shain, \& Bergey, 2012). Thus, it is evident to argue that religion plays a vibrant role in consumer decision making. Scholars have advised to examine CSI from cultural and religious perspective (Aliman et al., 2017; Kamaruddin \& Kamaruddin, 2009). Hafstrom et al. (1992) suggested that more research work in this area is needed. Likewise, Kamaruddin and Kamaruddin (2009) also suggested to use religious lens for validation of CSI. Similarly, Sprotles and Kendall (1986) directed future researcher for investigation of the concept in different settings for more generalizability.

Thus, purpose of study is two-fold; first to examine the CSI from religious sphere as Hirschman (1983) argued that religion obliges, as a guiding principle, for different consumer choices. Likewise, Ross (1991) argued that all major religions hold critical views on consumer consumptions that serves as consumption guidelines. Religious beliefs regularly affect marketplace ideologies and consumption patterns (Izberk-Bilgin, 2012). Muslims societies are greatly influenced by Islamic teachings (Kavoossi, 2000), even their consumption be- 
haviour is grounded on Islamic laws (Rehman \& Shahbaz Shabbir, 2010). Islam provides code of conduct to its followers for their public and private life activities as noted in Holy Qur'ān "Give to the near of kin his due, and also to the needy and the wayfarer. Do not squander your wealth wastefully, for those who squander wastefully are Satan's brothers, and Satan is ever ungrateful to his Lord." (17:26-27). Similarly Qur'ān in another verse advise his believers "eat and drink, but waste not by extravagance" (7:31). The second purpose of study is to investigate the CSI concept in economically developing region like Pakistan.

\section{LITERATURE REVIEW}

Rapid technological advancement provides easy access to consumer on information from different sources like articles, direct mailing, mobile based advertisements, and non-traditional advertisement. Abundance of information provides benefit to consumers also and makes the decision making more complex contrary to decision making previously. Apparently, it seems that consumer are facilitated in decision making with advancement of information and increased number of choices but, the situation became worse meanwhile (Hafstrom et al., 1992). In past, the scholars considered the shopping as complex and complicated phenomena (Siu, Wang, Chang, \& Hui, 2001). Researchers have identified three different traditional approaches for consumers shopping or purchasing decision making, such as: consumer characteristic approach, consumer typology approach and finally consumer psychographic/life style approach (Hanzaee, 2011). Consumer characteristic approach deals with cognitive ability of consumer's (Büttner, Florack, \& Serfas, 2014), whereas the consumer typology approach identifies several types and classes of consumers (Meyer \& Sullivan 2013). Likewise, researcher differentiated consumers on the basis of their behaviours and named it as the consumers psychological approach (Valentine \& Powers, 2013). Grounded on the said approaches, scholars identified different consumer shopping styles from recreational shoppers (Bellenger, 1980), economic consumers (Stone, 1954), loyal consumers (Stephenson \& Willett, 1969), impulse buyers (Gehrt \& Carter, 1992), brand conscious consumers (Korgaonkar, 1984), to quality seekers (Darden \& Ashton, 1974). Amongst all approaches, consumer characteristic approach gained relatively more attention than consumer typology and consumer psychographic approaches, as it was considered more rigorous due it focus on consumer's mental orientation (Lysonski et al., 1996). After in-depth review of consumers' decision making style, researchers, primarily Sprotles and Kendall (1986) highlighted 50 items consumer decision making inventory related to affective and cognitive decision making. In successive year, Sprotles and Kendall (1986) refined the initial 50 items inventory and came up with combined decision-making traits with more parsimonious scale of 40 items.

CSI developed by Sprotles and Kendall (1986) consists of 40 items with eight broad categories counting: "Perfectionism", "Price consciousness", "Novelty-fashion consciousness", "Confused", "Brand consciousness", "Recreational", "Impulsiveness", and "Habitual" (Akturan, Tezcan, \& Vignolles, 2011; Jamal, Davies, Chudry, \& Al-Marri, 2006). CSI concept is defined as basic consumer personality and the concept is related to the personality concept in psychology discipline. CSI explains both cognitive and affective perspectives of consumer choices (Siu et al., 2001). Sprotles and Kendall (1986) developed the inventory 
while examining a sample from the US, and asked for cross cultural investigation on the concept for its generalizability. Since its emergence, numerous scholars attempted to confirm its generalizability (Durvasula, Lysonski, \& Andrews, 1993; Fan \& Xiao, 1998; Hafstrom et al., 1992; Lysonski et al., 1996).

In response to call for generalizability and validation of 40 items inventory by the Sprotles and Kendall (1986), researchers like Hafstrom et al. (1992) investigated the CSI concept on Korean under-graduate students sample. The results confirmed original findings with extra factor of "time-energy conserving". Likewise, Durvasula et al. (1993) used under-graduate students from New Zealand to compare the findings with US sample. Results indicated some likeness and some variances between samples, and established the overall generality of the CSI.

Besides scholars concerns on generalizability of the scale, CSI is the most examined instrument available in marketing literature. Practitioners if intended to enter any new culture or segment can base their decision on CSI inventory. Segmentation and targeting, while employing CSI inventory, can provide competitive advantage to practitioners to serve their market effectively and efficiently. As past literature clearly indicates that decision making varies across different cultures, that's way scholars have examined the CSI on different cultures (Fan \& Xiao, 1998; Hafstrom et al., 1992; Lysonski et al., 1996); but its validation on religious ground in developing country like Pakistan is yet to be proven.

With globalization and technological advancement, junction and deviation increases that brings dramatic changes in local and regional cultures (Cleveland, Laroche, \& Hallab, 2013). However, effects of local ethnic sub cultures cannot be neglected that shape overall cultural values of the countries (Jamal et al., 2006). Religion provides basic guidelines to its followers within the local ethnic sub cultures. Religion is "a set of beliefs that are taught since childhood, and people gradually commit to the religion as they have greater understandings towards its teachings" (Alam, Mohd, \& Hisham, 2011). Religious commitment is known by how much its followers follow the guiding principles that shape beliefs and attitudes (Worthington Jr et al., 2003). Similarly, Greeley (1963) observed that behaviours are outcomes of religious and cultural interaction. Likewise, Lenski (1961) argued that religious group operates informally and shapes idiosyncratic norms of its believers. Despite of its importance, marketing intellectuals neglected this aspect. Study by Douglas (1976) was the first deliberate attempt to examine the impact of values and background on consumer behaviour. Later, Hirschman (1983) investigated the impact of religious association on different consumer choices. Hirschman (1983) empirical findings supported that religion obliges as a guiding principle for different consumer choices. Similarly Ross (1991) argued that all major religions hold critical view on consumptions that serves as consumption guidelines for their followers. Beliefs based on religious teachings regularly affect marketplace ideologies and consumption patterns (Izberk-Bilgin, 2012). Religious beliefs are considered as guiding standards of consumer behaviour to finalize their consumption decisions in markets. Although, Islam is growing religion in world such as it is the second largest religion in United States (Lewis, Turton, \& Francis, 2007), but scholars have only recently attempted to scrutinize Islamic teachings in different perspectives (Wilson \& Grant, 2013). 
This shift is considered due to greater influencing power of Muslims in all spheres of life like politics, economy, culture and more specifically with emerging trend of Muslims middle class that seek guidance from Islam and try to balance between their sacred values and product offerings. (Sand1kc1, 2011; Sobh, Belk, Wilson, \& Ginena, 2012). Religion not only provides spiritual guidelines, but also beacons their followers in their daily life decisions such as owing and purchasing of market offerings (Alam et al., 2011). Like any other religion, Islam provides code of conduct to its followers from religious obligations to daily life obligations such as buying and selling of goods and services (Al-Olayan \& Karande, 2000). Religious teachings can affect personal attitudes towards consumption (Burroughs \& Rindfleisch, 2002; Mokhlis, 2006). Muslims societies are greatly influenced by Islamic teachings (Kavoossi, 2000). Even consumption behaviours of Muslims are grounded on Islamic rules (Rehman \& Shahbaz Shabbir, 2010). As Allah Almighty commanded in His holy book, "eat and drink, but waste not by extravagance"(7:31). Additionally, Prophet Mohammad (SAW) once advised to his followers by saying, "Allah has hated for you three things: 1. Vain talks, (useless talk) that you talk too much or about others. 2. Wasting of wealth (by extravagance) 3. And asking too many questions (in disputed religious matters) or asking others for something" (See Al-Bukhari hadīth No. 591, Vol. Ill). It is very clear from Qur'ānic verses and Prophet's teaching that Muslims should look to Sharī'ah not only in their religious matters, but also in their daily (individualistic as well as collectivistic) affairs. According to Holy book "O you who have believed, enter into Islam completely [and perfectly] and do not follow the footsteps of Satan. Indeed, he is to you a clear enemy" (2:208). Therefore, it is hypothesized that Muslim consumers style inventory will be different from the original CSI of Sprotles and Kendall (1986).

\section{METHODOLOGY}

\section{Sample and Data Collection Procedure}

For the factor analysis, data was gathered from the under-graduate and graduate students via self-administrative questionnaire through convenient sampling technique. Previous studies of consumer decision making style also used students as a sample in their respective studies e.g., (Hafstrom et al., 1992; Kamaruddin \& Kamaruddin, 2009; Siu et al., 2001). Durvasula et al. (1993) believed that more rigorous results can be obtained by using student's sample. Likewise, Calder, Phillips, and Tybout (1981) argued that use of homogeneous sample rather than heterogeneous sample can reduce random errors. Thus, selection of university students sample was justified. A questionnaire encoding cover later for ensuring volunteer participation was distributed to 315 students. A questionnaire was divided into nine sub parts. First eight segments tap the response on original CSI developed by Sprotles and Kendall (1986). Last section was designed to capture demographic data of respondents which includes age, gender, highest qualification and monthly spending.

After getting permission from concerned authorities of host universities, questionnaires were distributed via professional and personal links of the researcher to 315 students of different universities with different backgrounds. Out of 300 returned questionnaire, total 283 questionnaires were deemed valid for further tests. The $89 \%$ response rate was satisfactory 
and considered reasonable in Asian context (Abbas, Raja, Darr, \& Bouckenooghe, 2014). Table 1 represents the demographic profile of respondents that includes 160 (56\%) male respondent and 123 (44\%) female respondents. Furthermore, table 1 shows that $40 \%$ of respondents were below 25 years age and $60 \%$ of them were above 25 years. $54 \%$ of them spent $(21,000$ to 35,000$)$ rupees on shopping, where as $13 \%$ of them had average spending above 35,000 rupees per month. While $70 \%$ of them were pursuing masters and MS degrees, $30 \%$ of them were in undergraduate programs.

TABLE 1

Demographic Statistics

\begin{tabular}{lll}
\hline \hline \multirow{2}{*}{ Age } & Respondents characteristic's & Parentage \\
& Less than 25 years & $40 \%$ \\
Gender & More than 25 years & $60 \%$ \\
& Female & $44 \%$ \\
Average monthly shopping Expense & Male & $56 \%$ \\
& Less than 35,000 rupees & $87 \%$ \\
& More than 35,000 rupees & $13 \%$ \\
Qualification & Under-graduate students & $30 \%$ \\
& Graduate students & $70 \%$ \\
\hline \hline
\end{tabular}

\section{Measures}

A 40 items inventory adopted by Sprotles and Kendall (1986) was used to gather data of Muslim consumers perception regarding different shopping orientations. A questionnaire with nine sub segments (including demographic part) was distributed to Muslims respondents, which consisted of all eight factor developed by Sprotles and Kendall (1986). Responses on all segments were taped by 5 point Likert scale rages from strongly disagree (1) to strongly agree (5). Amongst them, the first segment was related to "Perfectionistic" items where "Getting very good quality is very important to me and when it comes to purchasing products, I try to get the very best or perfect choice". Second factor was related to "Brand Conscious" items where "The well-known national brands are best for me and the more expensive brands are usually my choices". Third factor capture the response related to "Novelty-Fashion Conscious Consumer" items where "I usually have one or more outfits of the very newest style and I keep my wardrobe up-to-date with the changing fashions". Similarly, forth factor was related to "Recreational" items where "Shopping is not a pleasant activity to me (r), going shopping is one of the enjoyable activities of my life". "Price Conscious" was fifth factor in terms of which "I buy as much as possible at sale prices, and the lower price products are usually my choice. Sixth factor belongs to "impulsive" consumers, where "I should plan my shopping more carefully than I do and I am impulsive when purchasing". Factor seven belongs to "Confused by over choice Consumer" where "There are so many brands to choose from that often I feel confused and sometimes it's hard to choose which stores to shop. Lastly, data of "Habitual" consumers was obtained where "I have favourite brands I buy over and over, and once I find a product or brand I like, I stick with it". 


\section{Statistical Analysis}

SPSS statistics was employed to analyse the data. For factor analysis, initially correlation test was performed to identify similarity among the items. After the clearance from correlation analysis, Kesier-meyer-Olkin (KMO) for the suitability of factor analysis was performed along with Bartlett test of sphericity to test the assumption that variables are uncorrelated with each other. Later, as advised by Harman (1976), principle component technique for factor analysis was performed to find "maximum contribution of some of variance of n variables". Following the procedure of previous studies (Ilter, Bayraktaroglu, \& Ipek, 2017; Kamaruddin \& Kamaruddin, 2009), latent root criterion method was employed with eigenvalues above 1.0 considered for extraction of items. Furthermore, Varimax method was used for the rotation of factors. Only items with value above .05 were retained which is higher than the threshold value of .04 (Hair, Black, Babin, Anderson, \& Tatham, 2006).

TABLE 2

Factor Analysis of Muslims CSI

\begin{tabular}{lll}
\hline \hline Items & Eigenvalue & Variance (\%) \\
\hline Factor 1-Perfectionistic & 21.60 \\
When it comes to purchasing products, I try to get the 8.83 & \\
very best or perfect choice & & \\
Getting very good quality is very important to me. & & \\
In general, I try to buy the best overall quality. & & \\
I make special effort to choose the very best quality prod- & \\
ucts. & & \\
My standards and expectations for products I buy are & \\
very high. & \\
Factor 2-Novelty-Fashion Conscious Consumer & \\
Fashionable, attractive styling is very important to me & 3.16 \\
I keep my wardrobe up-to-date with the changing fash- & \\
ions & & \\
It's fun to buy something new and exciting. & \\
Factor 3-Confused by over choice Consumer & \\
There are so many brands to choose from that often I feel 2.90 \\
confused. \\
All the information I get on different products confuses \\
me. \\
Sometimes it's hard to choose which stores to shop. \\
The more I learn about products, the harder it seems to \\
choose the best.
\end{tabular}


TABLE 2

Continue

\begin{tabular}{|c|c|c|}
\hline$\overline{\text { Items }}$ & Eigenvalue & Variance $(\%)$ \\
\hline Factor 4-Brand Conscious & \multirow{5}{*}{2.13} & \multirow{5}{*}{5.20} \\
\hline The more expensive brands are usually my choices. & & \\
\hline The most advertised brands are usually very good choices. & & \\
\hline The higher the price of a product, the better its quality. & & \\
\hline $\begin{array}{l}\text { Nice department and specialty stores offer me the best } \\
\text { products. }\end{array}$ & & \\
\hline Factor 5-Price Conscious & \multirow{5}{*}{1.91} & \multirow{5}{*}{4.66} \\
\hline I buy as much as possible at sale prices. & & \\
\hline The lower price products are usually my choice. & & \\
\hline I look carefully to find the best value for the money. & & \\
\hline Factor 6-Habitual & & \\
\hline I go to the same stores each time I shop. & \multirow[t]{2}{*}{1.50} & \multirow[t]{2}{*}{3.673} \\
\hline $\begin{array}{l}\text { Once I find a product or brand I like, I stick with it. } \\
\text { I have favorite brands I buy over and over. }\end{array}$ & & \\
\hline
\end{tabular}

\section{RESULTS AND DISCUSSION}

The primary purpose of the factor analysis is to identify whether the 40 item CSI identified by Sprotles and Kendall (1986) in US sample is equally applicable on Muslim consumers. Secondly, we also wanted to test the validity and reliability of scale for generalizability as suggested by Sprotles and Kendall (1986). Kamaruddin and Kamaruddin (2009) identified Muslim consumers styles in Malaysia and our results are consistent and inline with that study. Referring to Table 2, results indicated that only 28 items with six factors were loaded instead of 40 items of eight factors. Moreover, Table indicated that the Eigenvalue is above 1. Table indicated that six factors solution is also adequate for measuring decision making as average variance explained was near 50\%. Furthermore, KMO value of .0793 with significance level of Bartlett's Test (0.000) provides the indication of appropriateness of this factor analysis.

All factors were named in line with the original work, as they somehow reflect the same decision-making styles, but in more parsimonious way. First factor conations 5 items, named as "Perfectionistic"; this dimension of decision making explains the variance of $21.641 \%$ with eigenvalue of $8.83>01$. Next factor covers total three items, named as "Novelty-Fashion Conscious Consumer" with eigenvalue of $3.167>01$ and responsible for $7.24 \%$ of variance. Similarly, third factor, named as "Confused by over choice Consumer" ( 4 items) explained $7.080 \%$ of variance with eigenvalue $>01$. Forth factor comprises 4 items and is named as "Brand Conscious", with eigenvalue $>01$ and variance 5.205\%. Fifth factor is named as Price Conscious ( 3 items) with eigenvalue $>01$ and variance explained is $4.6 \%$. Lastly, factor seven explained $3.6 \%$ of variance with eigenvalue $1.50>01$ and is named as "Habitual" consumers. 


\section{Reliability Analysis}

Cronbach (1951) approach was used to examine the internal consistencies of each factor. According to the suggestion of Nunnally and Bernstein (1967), minimum value of reliability coefficient .05 is sufficient. Table 3 depicts that all factors were loaded above .05 like "Perfectionistic" ( $\alpha=.872)$, "Novelty-Fashion Conscious Consumer" $(\alpha=.748)$, "Confused by over choice Consumer" ( $\alpha=.782)$, "Brand Conscious consumers" $(\alpha=.720)$, "Habitual Consumers" ( $\alpha=.731)$, except fifth factor of "Price Conscious" $(\alpha=.463)$. Similar trend can be traced in other studies, like Lysonski et al. (1996) found low reliability in Indian context.

Thus, it is evident from the study that Muslims consumers are different from others, the two factors such as "Impulsive consumers" and "Reactional consumer" were not supported in this study. These factors are not liked as per the core teachings of Islamic Sharī'ah, because of their tendency of money wastage and Qur'ān as also the Prophet (PBUH) clearly forbid its followers to do so, as indicated earlier in this paper.

TABLE 3

Reliability Statistics

\begin{tabular}{lll}
\hline \hline Muslims Consumer \& Style Inventory & Cronbach Alpha & Number of items \\
\hline Perfectionistic & .872 & 5 \\
Novelty-Fashion Conscious Consumer & .748 & 3 \\
Confused by over choice Consumer & .782 & 4 \\
Brand Conscious & .720 & 4 \\
Price Conscious & .466 & 3 \\
Habitual & .731 & 3 \\
\hline \hline
\end{tabular}

\section{CONCLUSION AND IMPLICATIONS}

The primary focus of this study is to find out the way how Muslims consumers interact in marketplace and to discover certain underlying assumption of shopping. Current research study is a valuable contribution to body of knowledge and also have important theoretical and managerial implications. It is the first attempt to find the CSI from the religious perspective and addressed the call of Kamaruddin and Kamaruddin (2009). Conceptualization of CSI on the basis of religion gives valuable implications to the practitioners of national and multinational brands to enhance their quality continually at suitable prices. Study findings imply that Muslim consumers are more quality conscious and put deliberate efforts for quality shopping.

Secondly, the "confused by over choice" dimension of study give alarming call to the academia, intellectuals and government agencies to put deliberate and sufficient effort to educate the household consumers. Concepts of market ethics or related values should be communicated to all concerned to be followed in letter and spirits, so that consumers might not be confused or exploited by paradox of choices and information overload. As in a Muslims dominated societies the clerics (prayer leaders and imām masajid) play a vital role in formation of opinion and attitude of their believers. Clerics, especially on pulpit should 
accept their responsibility and play their role in educating Islamic principles of consumption to Muslim consumers, formulate and amend their purchasing habits accordingly. Lastly, consumer themselves can get the advice from the findings of the study before consumption decisions.

There exists a significant difference between Muslim and non-Muslim consumers. This study contributes to the theory and practical aspect of coping up with the consumers who have a religion based grounding, with special focus to Muslim consumers. The scale which is endorsed and enhanced in this study will act as a helping mechanism to future researchers who might be interested in identifying variables relevant to Muslim consumers in other parts of the world. As highlighted by Zia and Shahzad (2017) Muslim consumers are different from other consumers and should be gauged with specialized research approach, and this study contributes to this argument implementation in research methodology.

\section{Limitation and Future directions}

Despite several beneficial findings, this study has some limitations as well that may give line to future researchers. First the sample size of study is limited not in numbers only but also limited in terms of population. We only used university students as sample, data from other segments like household consumers, madrassa students and professionals can give more insights. Secondly, we used cross sectional design; future researcher can use longitudinal design to gain more insights of consumers decision making orientation. Conceptualization and investigation of consumer decision making style from the personality type and religious belonging will have great contribution for the body of knowledge. Future researcher can use cross religious examination to have better understanding of the topic.

\section{REFERENCES}

Abbas, M., Raja, U., Darr, W., \& Bouckenooghe, D. (2014). Combined effects of perceived politics and psychological capital on job satisfaction, turnover intentions, and performance. Journal of Management, 40(7), 1813-1830.

doi: https://doi.org/10.1177/0149206312455243

Akturan, U., Tezcan, N., \& Vignolles, A. (2011). Segmenting young adults through their consumption styles: A cross-cultural study. Young Consumers, 12(4), 348-360. doi: https://doi.org/10.1108/17473611111185896

Alam, S. S., Mohd, R., \& Hisham, B. (2011). Is religiosity an important determinant on Muslim consumer behaviour in Malaysia? Journal of Islamic Marketing, 2(1), 83-96. doi: https://doi.org/10.1108/17590831111115268

Aliman, N. K., Ariffin, Z. Z., \& Hashim, S. M. (2017). Generation Y Muslim female and male decision making styles in Malaysia: Are they different? Journal of Research in Marketing, 7(2), 534-543. doi: https://doi.org/10.17722/jorm.v7i2.184

Al-Olayan, F. S., \& Karande, K. (2000). A content analysis of magazine advertisements from the United States and the Arab world. Journal of Advertising, 29(3), 69-82. doi: https://doi.org/10.1080/00913367.2000.10673618 
Bakewell, C., \& Mitchell, V. W. (2003). Generation Y female consumer decision-making styles. International Journal of Retail E Distribution Management, 31(2), 95-106. doi: https://doi.org/10.1108/09590550310461994

Bates, L. (1998). UK consumer decision-making styles. Journal of Marketing Management, 14(1-3), 199-225. doi: https://doi.org/10.1362/026725798784959345

Bellenger, D. N. (1980). Profiling the recreational shopper. Journal of Retailing, 56(3), 77-92.

Bettman, J. R. (1979). Memory factors in consumer choice: A review. Journal of Marketing, 43(2), 37-53. doi: https://doi.org/10.2307/1250740

Burroughs, J. E., \& Rindfleisch, A. (2002). Materialism and well-being: A conflicting values perspective. Journal of Consumer Research, 29(3), 348-370.

doi: https://doi.org/10.1086/344429

Büttner, O. B., Florack, A., \& Serfas, B. G. (2014). A dual-step and dual-process model of advertising effects: Implications for reducing the negative impact of advertising on children's consumption behaviour. Journal of Consumer Policy, 37(2), 161-182. doi: https://doi.org/10.1007/s10603-013-9250-0

Calder, B. J., Phillips, L. W., \& Tybout, A. M. (1981). Designing research for application. Journal of Consumer Research, 8(2), 197-207. doi: https://doi.org/10.1086/208856

Cleveland, M., Laroche, M., \& Hallab, R. (2013). Globalization, culture, religion, and values: Comparing consumption patterns of Lebanese Muslims and Christians. Journal of Business Research, 66(8), 958-967. doi: https://doi.org/10.1016/j.jbusres.2011.12.018

Cronbach, L. J. (1951). Coefficient alpha and the internal structure of tests. Psychometrika, 16(3), 297-334. doi: https://doi.org/10.1007/bf02310555

Darden, W. R., \& Ashton, D. (1974). Psychographic profiles of patronage preference groups. Journal of Retailing, 50(4), 99-112.

Delener, N. (1990). The effects of religious factors on perceived risk in durable goods purchase decisions. Journal of Consumer Marketing, 7(3), 27-38.

doi: https://doi.org/10.1108/eum0000000002580

Douglas, S. P. (1976). Cross-national comparisons and consumer stereotypes: A case study of working and non-working wives in the US and France. The Journal of Consumer Research, 3(1), 12-20. doi: https://doi.org/10.1086/208646

Durvasula, S., Lysonski, S., \& Andrews, J. C. (1993). Cross-cultural generalizability of a scale for profiling consumers' decision-making styles. Journal of Consumer Affairs, 27(1), 55-65. doi: https://doi.org/10.1111/j.1745-6606.1993.tb00737.x

Fan, J. X., \& Xiao, J. J. (1998). Consumer decision-making styles of young-adult Chinese. Journal of Consumer Affairs, 32(2), 275-294. doi: https://doi.org/10.1111/j.1745-6606.1998.tb00410.x

Gehrt, K. C., \& Carter, K. (1992). An exploratory assessment of catalog shopping orientations. The existence of convenience and recreational segments. Journal of Direct Marketing, 6(1), 29-39. doi: https://doi.org/10.1002/dir.4000060107

Greeley, A. M. (1963). Influence of the "religious factor" on career plans and occupational values of college graduates. American Journal of Sociology, 68(6), 658-671. doi: https://doi.org/10.1086/223463 
Hafstrom, J. L., Chae, J. S., \& Chung, Y. S. (1992). Consumer decision-making styles: comparison between United States and Korean young consumers. Journal of Consumer Affairs, 26(1), 146-158. doi: https://doi.org/10.1111/j.1745-6606.1992.tb00020.x

Hair, J. F., Black, W. C., Babin, B. J., Anderson, R. E., \& Tatham, R. L. (2006). Multivariate data analysis. Upper Saddle River, NJ: Prentice Hall.

Hanzaee, K. H. (2011). Influence of family structure on consumer decision-making style in Iran. International Journal of Business and Management, 6(11), 297-304. doi: https://doi.org/10.5539/ijbm.v6n11p297

Harman, H. H. (1976). Modern factor analysis. Chicago, IL: University of Chicago Press. Hilary, G., \& Hui, K. W. (2009). Does religion matter in corporate decision making in America? Journal of Financial Economics, 93(3), 455-473.

doi: https://doi.org/10.1016/j.jfineco.2008.10.001

Hirschman, E. C. (1983). Religious affiliation and consumption processes: An initial paradigm. Research in Marketing, 6(1), 131-170.

Hiu, A. S., Siu, N. Y., Wang, C. C., \& Chang, L. M. (2001). An investigation of decisionmaking styles of consumers in China. Journal of Consumer Affairs, 35(2), 326-345. doi: https://doi.org/10.1111/j.1745-6606.2001.tb00117.x

Ilter, B., Bayraktaroglu, G., \& Ipek, I. (2017). Impact of Islamic religiosity on materialistic values in Turkey. Journal of Islamic Marketing, 8(4), 533-557. doi: https://doi.org/10.1108/jima-12-2015-0092

Izberk-Bilgin, E. (2012). Infidel brands: Unveiling alternative meanings of global brands at the nexus of globalization, consumer culture, and Islamism. Journal of Consumer Research, 39(4), 663-687. doi: https://doi.org/10.1086/665413

Jacoby, J., Chestnut, R. W., \& Fisher, W. A. (1978). A behavioral process approach to information acquisition in nondurable purchasing. Journal of Marketing Research, 15(4), 532-544. doi: https://doi.org/10.1177/002224377801500403

Jamal, A., Davies, F., Chudry, F., \& Al-Marri, M. (2006). Profiling consumers: A study of Qatari consumers' shopping motivations. Journal of Retailing and Consumer Services, 13(1), 67-80. doi: https://doi.org/10.1016/j.jretconser.2005.08.002

Kamaruddin, A. R., \& Kamaruddin, K. (2009). Malay culture and consumer decisionmaking styles: An investigation on religious and ethnic dimensions. Jurnal Kemanusiaan, 7(2), 37-50

Kavas, A., \& Yesilada, F. (2007). Decision making styles of young Turkish consumers. European Journal of Economics, Finance and Administrative Sciences, 9(11), 73-85.

Kavoossi, M. (2000). The globalization of business and the Middle East: Opportunities and constraints. West Port, CT: Greenwood Publishing Group.

Korgaonkar, P. K. (1984). Consumer shopping orientations, non-store retailers, and consumers' patronage intentions: A multivariate investigation. Journal of the Academy of Marketing Science, 12(1-2), 11-22. doi: https://doi.org/10.1007/bf02729483

Lenski, G. E. (1961). The religious factor: A sociological study of religion's impact on politics, economics, and family life. Garden City, NY: Doubleday. 
Lewis, C. A., Turton, D. W., \& Francis, L. J. (2007). Clergy work-related psychological health, stress, and burnout: An introduction to this special issue of Mental Health, Religion and Culture. Mental Health, Religion $\mathcal{E}$ Culture, 10(1), 1-8.

doi: https://doi.org/10.1080/13674670601070541

Lysonski, S., Durvasula, S., \& Zotos, Y. (1996). Consumer decision-making styles: S multi-country investigation. European Journal of Marketing, 30(12), 10-21. doi: https://doi.org/10.1108/03090569610153273

Maynes, E. S. (1976). Decision-making for consumers: An introduction to consumer economics. Upper Saddle River, NJ: Prentice Hall.

McDonald, W. J. (1994). Developing international direct marketing strategies with a consumer decision-making content analysis. Journal of Direct Marketing, 8(4), 18-27. doi: https://doi.org/10.1002/dir.4000080405

Meyer, B. D., \& Sullivan, J. X. (2013). Consumption and income inequality and the great recession. American Economic Review, 103(3), 178-83.

doi: https://doi.org/10.1257/aer.103.3.178

Miller, J. (1981). Global precedence in attention and decision. Journal of Experimental Psychology: Human Perception and Performance, 7(6), 1161. doi: https://doi.org/10.1037/0096-1523.7.6.1161

Mokhlis, S. (2006). The influence of religion on retail patronage behaviour in Malaysia (Phd thesis). University of Stirling, Stirling, Scotland.

Nunnally, J. C., \& Bernstein, I. H. (1967). Psychometric theory (vol. 226). New York, NY: McGraw-Hill.

Patel, N., Vila-López, N., \& Kuster-Boluda, I. (2013). Differences between American and Indian consumers' visual images. Cross Cultural Management: An International Journal, 20(1), 50-67. doi: https://doi.org/10.1108/13527601311296256

Radder, L., Li, Y., \& Pietersen, J. J. (2006). Decision-making styles of young Chinese, Motswana and Caucasian consumers in South Africa: An exploratory study. Journal of Consumer Sciences, 34(1), 20-31. doi: https://doi.org/10.4314/jfecs.v34i1.52902

Renneboog, L., \& Spaenjers, C. (2012). Religion, economic attitudes, and household finance. Oxford Economic Papers, 64(1), 103-127. doi: https://doi.org/10.1093/oep/gpr025

Ross, S. A. (1991). Freedom from possession: The Tibetan Buddhist view. Journal of Social Behavior and Personality, 6(6), 415-426.

Sandıkcı, Ö. (2011). Researching Islamic marketing: Past and future perspectives. Journal of Islamic Marketing, 2(3), 246-258. doi: https://doi.org/10.1108/17590831111164778

Schommer-Aikins, M. (2004). Explaining the epistemological belief system: Introducing the embedded systemic model and coordinated research approach. Educational Psychologist, 39(1), 19-29. doi: https://doi.org/10.1207/s15326985ep3901_3

Shabbir, M. S. (2010). The relationship between religiosity and new product adoption. Journal of Islamic Marketing, 1(1), 63-69.

doi: https://doi.org/10.1108/17590831011026231

Sigalow, E., Shain, M., \& Bergey, M. R. (2012). Religion and decisions about marriage, residence, occupation, and children. Journal for the Scientific Study of Religion, 51(2), 304-323. doi: https://doi.org/10.1111/j.1468-5906.2012.01641.x 
Siu, N. Y., Wang, C. C., Chang, L. M., \& Hui, A. S. (2001). Adapting consumer style inventory to Chinese consumers: A confirmatory factor analysis approach. Journal of International Consumer Marketing, 13(2), 29-47. doi: https://doi.org/10.1300/j046v13n02_03

Sobh, R., Belk, R., Wilson, J., \& Ginena, K. (2012). Home and commercial hospitality rituals in Arab Gulf countries. Advances in Consumer Research 40, 5-8

Sprotles, G. B., \& Kendall, E. L. (1986). A methodology for profiling consumers' decisionmaking styles. Journal of Consumer Affairs, 20(2), 267-279.

doi: https://doi.org/10.1111/j.1745-6606.1986.tb00382.x

Stephenson, P. R., \& Willett, R. P. (1969). Analysis of consumers' retail patronage strategies. In P. R. McDonald, (Ed.). Marketing involvement in society and the economy. Chicago, IL: American Marketing Association.

Stone, G. P. (1954). City shoppers and urban identification: Observations on the social psychology of city life. American Journal of Sociology, 60(1), 36-45. doi: https://doi.org/10.1086/221483

Valentine, D. B., \& Powers, T. L. (2013). Generation Y values and lifestyle segments. Journal of Consumer Marketing, 30(7), 597-606. doi: https://doi.org/10.1108/jcm-07-2013-0650

Walsh, G., Hennig-Thurau, T., Wayne-Mitchell, V., \& Wiedmann, K. P. (2001). Consumers' decision-making style as a basis for market segmentation. Journal of Targeting, Measurement and Analysis for Marketing, 10(2), 117-131.

doi: https://doi.org/10.1057/palgrave.jt.5740039

Walsh, G., Mitchell, V.-W., \& Hennig-Thurau, T. (2001). German consumer decisionmaking styles. Journal of Consumer Affairs, 35(1), 73-95.

doi: https://doi.org/10.1111/j.1745-6606.2001.tb00103.x

Wilson, J. A., \& Grant, J. (2013). Islamic marketing-a challenger to the classical marketing canon? Journal of Islamic Marketing, 4(1), 7-21.

doi: https://doi.org/10.1108/17590831311306327

Worthington Jr, E. L., Wade, N. G., Hight, T. L., Ripley, J. S., McCullough, M. E., Berry, J. W., ... \& O'Connor, L. (2003). The religious commitment inventory-10: Development, refinement, and validation of a brief scale for research and counseling. Journal of Counseling Psychology, 50(1), 84-96. doi: https://doi.org/10.1037/0022-0167.50.1.84

Zia, M. H., \& Shahzad, K. (2017). Interpersonal influence as psycho social stressor, stress, and impulsive buying: An empirical study in the perspective of Islamic guidelines on consumption. Journal of Islamic Business and Management 7(2), 211-229.

doi: https://doi.org/10.26501/jibm/2017.0702-005 